\title{
Power Politics and the Rule of Law in Post-Dayton Bosnia
}

\author{
TIMOTHY DONAIS \\ Wilfrid Laurier University, Canada
}

\begin{abstract}
Over the past two decades, the rule of law has emerged as a key priority within contemporary peacebuilding efforts. Drawing on examples from post-Dayton Bosnia, this article examines the impact of rule of law reform efforts on broader patterns of power and political authority in peacebuilding contexts. It suggests that in the case of Bosnia, the use of rule of law strategies to restructure political life has largely failed. Thus, despite some notable achievements on the rule of law front, the core dynamics of Bosnia's political conflict remain intact, and country's peace process is as fragile as ever. The article concludes by noting that charting a course between accepting the political status quo and fundamentally transforming it requires more nuanced approaches that advance the rule of law even while accepting its limits as an instrument of deep political transformation.
\end{abstract}

\section{Introduction}

Some years ago in Bosnia, I met a Canadian civil servant who had been seconded to the Office of the High Representative (OHR) and who was tasked with helping to develop state-level transportation legislation. After months of extensive consultations with relevant stakeholders across the country, he had become disillusioned with the divisiveness of Bosnian politics, and resolved to spend his remaining months in the country producing a draft law in the quiet, uninterrupted comfort of his Sarajevo office. I do not know what became of the man or his legislation, but his story has stayed with me. It illustrates the wide gap that exists between the lofty ambitions of the broader international community in terms of bringing justice and the rule of law to war-afflicted countries and the messy, compromising realities of the effort to translate that vision into practice. The Canadian's story is also a good example of the technocratic impulse at work in contemporary rule of law programming, a 
tendency rooted in the broader hope that good laws, whatever their origin, ultimately can triumph over bad politics. As David Chandler (2004) has argued, however, the belief that international officials can develop better laws than the citizens of post-conflict states or their elected representatives is often little more than a bureaucratic fantasy; the obvious danger is that "law that is disassociated from the political process of consensus-building ... is more a rhetorical statement of policy intent than a law of the land" (p. 578-579).

Such considerations open up an even broader set of questions about the means and ends of rule of law reforms in post-conflict settings, and about the broader linkages among the rule of law, peace, and justice. While the promotion of the rule of law has become part of the standard recipe for postconflict peacebuilding - indeed, Brian Tamanaha (2004, p. 4) suggests that the rule of law may in fact be "the preeminent legitimating political ideal in the world today"- the widespread consensus surrounding its inherent desirability obscures a troubling lack of consensus around what it actually is or how it can be brought into being. Definitional debates surrounding the rule of law typically span the spectrum from thin versions, which emphasize the need for all government action to be authorized by law, to thicker versions, which stress the capacity of law to limit or constrain government action and may even imply "the affirmative duty of the government to make the lives of citizens better, distribute resources justly, and recognize the right to dignity" (Jensen, 2008, p. 123). Opinion is also divided on how to meet the challenge of constructing the rule of law in environments where it does not exist, such as in the vast majority of war-torn contexts in which peacebuilding is undertaken. The conventional view, which is influenced by modernization theory and its embedded assumptions about the linearity of development processes, focuses on institutional isomorphism and the orderly importation of Western norms and institutions into non-Western contexts. This perspective has increasingly come under fire however, by those who contend that rule of law reforms must take into consideration pre-existing norms, customs, practices, and even politics of the reforming society if they are to take root (Park, 2010; Peterson, 2010). On this account, the normative underpinnings of the rule of law are no less critical than its formal institutional structures. Rendering rule of law reforms in ways that are familiar and legitimate to both powerful domestic elites and society writ large is essential to their long-term viability; in this sense, rule of law reformers must carefully navigate both political interest and political culture if they hope to make a sustainable difference.

Set within this broader context, this contribution focuses on the impact of rule of law reform efforts on broader patterns of power and political authority in peacebuilding contexts. This emphasis is premised on the argument that at its core, the rule of law is about power: how it is constituted, how it is exercised, and how it is controlled. Hence, a key part of the rule of law's attractiveness in peacebuilding contexts lies in its potential role in re-ordering and re-structuring power relations as one key element of the larger task of reconstituting a new social contract between state and society (Pouligny, 2005). Taking post-Dayton Bosnia as a case study, the analysis 
of the relationship among power, law, and peace is used to explain an apparent paradox of contemporary peacebuilding in Bosnia: that despite considerable emphasis, and substantial achievements, on the rule of law front in recent years, the country's peace process remains as fragile as ever, while few Bosnians would consider themselves to be inhabitants of a just society. The primary argument to be developed here is that despite the manifest institutional changes brought about in the name of the rule of law in Bosnia, the underlying structure and core dynamics of political power and political contestation remain largely unaltered, which perpetuates a condition of structural injustice. Thus, while rule of law reforms may be may have inherent value, the Bosnia experience suggests that they in fact may be of limited use as a means to achieve broader political goals, at least within the relatively narrow time frames of conventional peace operations.

\section{Peacebuilding and the Rule of Law}

In the post-cold war era, the rule of law has emerged as part of the contemporary common sense of post-conflict peacebuilding, and stands along with human rights, democracy, and free markets as one of the key pillars of the dominant liberal peacebuilding paradigm. Indeed, while there has been considerable critical scrutiny of the practical consequences of both economic liberalization and political democratization in post-war environments (Paris, 2004), the desirability of advancing the rule of law in post-war settings has remained largely unchallenged. No doubt this is partly caused by the inherent undesirability of alternatives; neither lawlessness nor the rule of the gun has much to commend it as policy prescription. It is also because of the particular nature of the rule of law as a foundation or background condition without which many of the other key public goods viewed as essential to peace-from economic development to responsible, accountable government to universal human rights protections - cannot be realized.

In Bosnia, as elsewhere, a deepening appreciation of the importance of the rule of law to meeting the challenges of peace, order, and good government has been a key driver of the rapidly-expanding international peacebuilding agenda in recent decades. While the original focus on mediating and monitoring political settlements among warring factions remains, peacebuilding has increasingly come to be associated with statebuilding (Call \& Wyeth, 2008), and the scope of rule of law interventions has subsequently expanded to fill this much broader framework. From traditional rule of law work such as vetting and training judges and law enforcement personnel, the rule of law agenda now typically includes, inter alia, drafting and promulgating legislation from constitutions to civil and criminal procedure codes, combating organized crime and corruption, enforcing property rights, prosecuting war criminals, and working to ensure access to justice. As well, it includes strengthening the full range of domestic institutions charged with upholding the rule of law, including oversight and accountability mechanisms. 
To the extent that the means, if not the ends, of the rule of law agenda in contemporary peacebuilding have been questioned, a key critique has zeroed in on the extent to which the rule of law has been seen as a means through which political conflict in post-war environments can be either transcended or circumvented by the technocratic application of legal reforms. Augustine Park (2010) refers to this as the "rule of law fable," rooted in the belief that war and its end presents "an opportunity to build a new liberal legal culture that pledges peacefulness - a goal to be accomplished through technical institution-building" (p. 414). The fundamental premise here, as Park notes, is that "to be peaceful is to be like us," (p. 413) the implication being that war-torn societies should embrace uncritically the rule of law paradigm, with its roots firmly in the Western liberal democratic tradition, as both inherently superior to their own traditions of socio-political order and as the most reliable route to a sustainable, just peace. Similarly, Oliver Richmond and Jason Franks (2007) argue that the persistent belief on the part of Western interveners that liberal-democratic norms and institutions can be transferred progressively to fragile war-torn states is a manifestation of liberal hubris, and suggests that this practice has led more often than not to cases of "virtual peace," in which external norms and institutions are thinly-rooted and have minimal impact on domestic governance practices.

While much rule of law work is inherently technical and legalistic, it is also both normative and political. As has long been understood, the rule of law comprises both macro-level structures and micro-level commitments (Stromseth, Wippman, \& Brooks, 2006, p. 13). The practical experiences of post-cold war peacebuilding have exposed as naïve the belief that the introduction of liberal democratic institutions could, within a relatively short period, not only contain and ultimately resolve conflict but also transform the interests, goals and values of those actors who have to live with, and animate, the rule of law in their own cultural contexts. As Robert Fatton (2002) has suggested, there is a profound difference between writing a constitution and constitutionalism, "between writing a founding charter and adhering to its norms and rules" (p. 158). More precisely, the rule of law operates through both the logic of consequences and the logic of appropriateness: citizens and officials need to adhere to, and feel bound by, the rule of law not only because they fear the consequences of being on the wrong side of the law, but also because they believe that being on the right side of the law is the appropriate thing to do.

To the extent that the international community has absorbed the lesson that rule of law reforms themselves do not necessarily generate either law-abiding citizens or public service-oriented officials, the search for supplementary sources of legitimacy in which to ground the rule of law has generated growing interest in informal and/or traditional justice practices within conflictaffected states. There has been, more generally, a rediscovery of "the local" among both scholars and practitioners of peacebuilding in recent years. There is also a growing acceptance that local practices, institutions, and cultures may represent not simply obstacles to be transcended but also resources that 
could be harnessed in the name of peace. This shift has been represented in the growing attention to questions of national or local ownership (Donais, 2012), as well as in the growing literature on hybridity, which increasingly takes for granted that peacebuilding outcomes cannot be precisely engineered by outsiders, but rather emerge from the dynamic interplay of norms, practices, and politics across the international-domestic divide (Mac Ginty, 2011). The Development Assistance Committee of the Organization for Economic Co-operation and Development (OECD), in fact, has recently argued that "grounded legitimacy," pursued through "deliberate strategies for supporting the marriage of indigenous, customary and communal institutions of governance with introduced, Western state institutions, with a view to creating constructive interaction and positive mutual accommodation," should be a key guiding principle in efforts to rebuild fragile or war-torn states (OECD, 2011, p. 38).

The practical implications of the growing emphasis on local agency and local culture can already be seen in the practices of post-conflict rule of law reform, even if they have not yet been internalized fully. There is growing acceptance among international practitioners that the search for ways to ground rule of law reforms in locally-legitimate practices and traditions may be essential to their acceptance and longer-term sustainability. This can be seen in the widespread international endorsement of, and interest in, the use of gacaca trials in Rwanda as a homegrown alternative to conventional outside-in forms of transitional justice (Betts, 2005), and in the increased attention paid to non-state and informal justice mechanisms in contexts such as Afghanistan (Dempsey \& Coburn, 2010). What may be emerging gradually, therefore, is a shift towards viewing the rule of law in terms of the pursuit of context-specific outcomes which blend elements of the local and the international but remain largely acceptable across both sides of this divide. However, such a synthesis may prove difficult to generate in practice. Just as domestic actors may view the institutional practices and normative principles of liberal peacebuilding as foreign impositions, international actors should not be expected to compromise easily, or publicly, on core universal principles (human rights being perhaps the most iconic), in the name of cultural relativism. Park (2010), for example, suggests that it is already possible to discern one international strategy that has emerged in response to the challenge of culture in peacebuilding contexts, which is formally "multicultural accommodationist" in orientation but which, in reality, "hollows out, contains and tames culture within the authority of the rule of law" (p. 427).

Second, the greater objective of advancing the rule of law in post-conflict contexts is a political project just as much as it is a normative project. Rule of law reforms aim to alter to greater or lesser degrees the way in which political power is allocated, exercised and controlled. Indeed, one of the primary goals of the rule of law is to channel social and political behaviour among both citizens and governments along regularized, institutionalized, and predictable patterns. In this sense, if peacebuilding can be understood 
as an ongoing effort to establish a legitimate, stable socio-political orderan understanding which is consistent both with the use of social contract theory in the context of war-to-peace transitions and with the association of state building with the strengthening of state-society relations - then the terms of this new order are likely to be contested fiercely by those domestic political forces that stand to win or lose from it. The ultimate goal may be to reach a point where the rule of law serves, largely unseen and unchallenged, as a neutral and apolitical arbiter among contending social and political forces. Given the stakes involved, however, the process of negotiating such a framework - especially in acrimonious, fearful, and mutually-distrustful post-conflict landscapes - can never be above politics.

In contrast to recent advances in thinking about the role of culture in post-conflict rule of law reforms, on issues of power and politics the debate remains suspended between what Georg Sorensen (2006) has termed the liberalism of restraint and the liberalism of imposition. Despite the widely-recognized limitations of a strictly technical approach to rule of law reform among practitioners, there remains considerable discomfort with the implications of accepting rule of law reform as an explicitly political project that would be aimed self-consciously at re-structuring power relations within post-conflict spaces. Indeed, the rule of law fable may serve a useful legitimating function for international intervention, which enables external actors to frame the liberal reform agenda as neutral and unthreatening, and therefore acceptable to existing power-holders. However, as Paul Kingston (2012) has recently noted, the broader peacebuilding project also displays contradictory impulses in its relationship to the domestic power structures of post-conflict states. While the practices of elite pact-making contribute to the legitimation and consolidation of the power of existing elites (whose participation in peacemaking processes is usually contingent on such legitimation), the centrality of human rights, democracy, and the rule of law in contemporary peacebuilding is simultaneously geared towards empowering "the unorganized, and poor, and the marginalized" (pp. 333334). In the context of rule of law reforms, this tension between continuity and change - or more precisely between acknowledging and subverting existing power relations-predictably has often led to both inconsistent policies and suboptimal outcomes. For example, international efforts to deal with post-conflict warlords often run the gamut from appeasement and cooptation to criminalization and marginalization, while newly-introduced or newly-reformed rule of law institutions are often vulnerable to elite capture. Finally, all of this points back to the nature of international power and authority in post-conflict contexts: if, as is increasingly clear, the rule of law paradigm does not possess unquestioned legitimacy among all relevant actors in peacebuilding contexts, the outcomes of rule of law reforms will depend mainly on how the capacity of international actors to advance the rule of law (through the deployment of economic resources, political pressure, or physical coercion) matches up against the capacity of key domestic actors to resist, subvert, or redirect reform efforts. 
Post-Dayton Bosnia provides a rich case study through which to explore the political dynamics of rule of law reforms in peacebuilding contexts. Not only is Bosnia a mature peacebuilding operation, it is also one in which various rule of law reforms have played a central role. Bosnia is also a context in which cultural questions - particularly as they relate to the rule of law-have been largely absent. Since few indigenous legal traditions or institutions have survived the ongoing transition both from conflict and from socialism, there has been little debate on either side of the international-local divide about the extent to which rule of law reforms need to be reconciled with the pre-war traditions and practices of the Yugoslav state. Stripped of the complicating dimensions of culture and tradition, therefore, the political nature of - and the political contestation around - the international community's rule of law agenda in Bosnia become readily apparent, even if the dilemmas they present for international policy and practice are not so readily resolved.

\section{Peacebuilding through the Rule of Law in Bosnia}

Fully 17 years after the signing of the Dayton Peace Accords, which brought nearly four years of ethnic conflict to a halt in late 1995, Bosnia stands as a paradox of contemporary peacebuilding, with both success and failure in nearly equal measure. On the positive side, much progress has been made in transforming the empty shell of the Bosnian state that remained after Dayton, a condition reinforced by the peace agreement, which vested most governing authority in two ethnically-defined entities, the Muslim-Croat Federation and Republika Srpska (RS), into something resembling a contemporary, even Westphalian state. Today, the Bosnian state now can claim almost a monopoly on the legitimate use of force, with a single national armed forces (multi-ethnic Bosnian units even serve abroad as peacekeepers) as well as a state-level border service and intelligence agency under the control of the state government in Sarajevo. The country's judicial and law enforcement apparatus also, increasingly resembles that of other federal states, and the country's state-level court has even taken on responsibility for contentious domestic war crimes cases. Bosnia, as the US diplomat Douglas Davidson (2009) has noted, now possesses "most of the necessary trappings of a modern liberal democratic state" (p. 1) Finally, the presence of Ratko Mladic and Radovan Karadzic at the International Criminal Tribunal for the Former Yugoslavia in the Hague is also a tremendously important signal that longdelayed justice for war crimes is slowly being delivered.

Despite the considerable progress that has been made toward the development and consolidation of a Bosnian state and society governed by the rule of law, Bosnia remains deeply dysfunctional, mired in an ongoing existential and constitutional crisis, and unable to govern itself for the wider benefit of its citizens. Following the most recent round of national elections in October 2010, fourteen months of divisive political wrangling were required to form a state-level government (which broke down after less than 
six months), while progress towards European Union accession-widely accepted by all sides as the logical endpoint of the peacebuilding processhas stalled completely. Relations among Bosnia's three main ethnic groups have deteriorated to the point where some observers have openly raised the prospects of renewed warfare (Azinovic, Bassuener, \& Weber, 2011), while the gap between the governors and the governed is wider than ever. Recent polling numbers, in fact, suggest that is reflected in recent polling numbers which suggest that nearly 85 per cent of Bosnians consider their country to be heading in the wrong direction (NDI, 2010). As the International Crisis Group (2012, p. 1) has recently noted, tension between Bosnia's two entities and three main ethnic groups is reaching a breaking point and there is an ongoing crisis of governance at both state and entity levels, all while "politicians ignore difficult policy choices and seem immune to domestic or international pressure." Ultimately, despite more than a decade and a half of intrusive peacebuilding efforts by the international community, the fundamental issue that precipitated Yugoslavia's disintegration-whether its different ethnic communities could, or wish to, live together-remains not only unresolved in the Bosnian case but continues to serve as a core obstacle on the country's path towards normalization.

Reconciling the significant advances on the rule of law reform front with the dismal political realities of contemporary Bosnia requires an understanding of the relationship between the international community's broader statebuilding agenda and the persistence of a resilient political economy of ethnic nationalism within Bosnia. While the original Dayton deal was based on the assumption that the local parties to the agreement would serve as its primary agents of implementation, the manifest absence of progress over the first several years of implementation exposed such hopes as radically misplaced. Dayton is, in fact, more of a ceasefire than a comprehensive political settlement, and its fundamental ambiguity on key issues such as the return of refugees and displaced persons meant that for the local parties, the post-Dayton period was more about continuing the conflict by other means - reversing Clausewitz, as Roberto Belloni $(2009$, p. 360) has noted - than about collaborating across ethnic lines to build a new Bosnian state. Indeed, for the Bosnian Serbs, and to a lesser extent the Bosnian Croats, the very existence of a sovereign Bosnian state within the original republican borders of Bosnia's Yugoslav incarnation has remained a fundamental point of contestation (Hayden, 2005). Beyond failing to provide a durable framework for the resolution of Bosnia's underlying conflict, the Dayton agreement has also sustained this conflict through a consociational political system which institutionalized ethnic divisions at all levels of the country's political system. Similarly, by allowing the country's political parties to avoid having to seek support beyond their own ethnic constituencies, Bosnia's electoral system has consistently rewarded hardline political positions, discouraged the politics of conciliation and moderation, and undermined the development of bonds of accountability between electors and the elected. Locked as it is in a political dynamic characterized by zero-sum ethnic politics, Bosnia's political system, 
as one political analyst has suggested, "is not capable of self-reform."

Thus, the shift towards a more intrusive international approach to the problems of peacebuilding in Bosnia, and the adoption of an explicit state building agenda as the manifestation of this new approach, can be traced back to the fundamental ambiguities of the original peace deal, to the profound ambivalence of Bosnia's three main ethnic communities towards it, and to a set of political incentive structures that reinforced rather than reversed the politics of ethnic confrontation. The so-called Bonn powers, which were adopted by an obviously frustrated international community in late 1997, dramatically shifted both legislative and executive power away from Bosnia's own duly-elected authorities and towards the Office of the High Representative (OHR) in the name of re-energizing a moribund peace process and creating the institutional foundations of a functioning Bosnian state. In the process, they also worked against Bosnia's emerging democracy, most dramatically by making the country's elected officials more accountable to Dayton's international guarantors than to the Bosnian electorate. The Bonn powers represented a signal shift in international approach towards a liberalism of imposition, and until the international state building agenda lost steam in 2006 with the departure of the Paddy Ashdown as High Representative, a great deal of institutional reform was achieved, and much of it was implemented in the name of the rule of law. With the benefit of hindsight, however, it now seems apparent that while reforms were wideranging they were also thinly-rooted, and structural reforms failed to alter fundamentally either political power structures or political behaviour. As the OHR's Mark Wheeler has noted, "we kept waiting for reforms to generate self-sustaining momentum, but it never happened."2 With regard to rule of law reform specifically, this dynamic can be seen in two key areas of the broader reform agenda: police reform and anti-corruption.

\section{Police Reform}

Operating at the interface between state and society, police are the most prominent, and arguably the most important, manifestation of the rule of law in practice, and they represent an indispensable element of both good governance and sustainable peace. As Paddy Ashdown remarked during his tenure as High Representative, "professional police forces, operating within the rule of law, and at the service of the citizen, are the hallmark of any decent, peaceful, civilized community" (cited in Collantes Celador, 2005, pp. 364-365).

However, in practice the challenges of reforming police are considerable in the best of situations. The task of moving law enforcement agencies in postwar contexts - in which the police have been corrupted, politicized and even criminalized to greater or lesser degrees - along the continuum towards an ideal-typical model of a professional, impartial, and apolitical public service has proven to be both politically sensitive and enormously complicated. As 
with any complex organization, reforming law enforcement agencies involves both institutional and socio-cultural components: structures must be altered to enhance efficiency, effectiveness, and accountability, while the individuals operating within that structure must progressively internalize the values inherent in the rule of law (Muehlmann, 2007, p. 378). At the same time, the reform process involves both technical and political dimensions: personnel need to be trained, equipped, and managed appropriately while in democratic contexts the need for appropriate political oversight must be balanced against the dangers of inappropriate political interference. Indeed, in the case of police reform, the political stakes are especially high since authority over policing - and hence over a central instrument of state's monopoly on the legitimate use of force-is a source of enormous political power.

In mid-2012, more than a decade-and-a-half of formal international police assistance to Bosnia came to a close with the winding-down of the European Union Police Mission (EUPM). The EUPM had succeeded the UN's International Police Task Force (IPTF) at the end of 2002. Perhaps the most accurate characterization of the balance-sheet of both missions is that while they succeeded in ensuring that Bosnia's police forces, in the context of the broader peacebuilding challenge in Bosnia, are no longer part of the problem, they were less successful in making the police part of the solution (Collantes Celador, 2005, p. 372). Important technical and institutional reforms have been put in place that have improved policing practice in Bosnia considerably, which in turn has contributed to a relatively stable public security environment and to fewer human rights abuses within the police services. On the other hand, the reform record has been less positive on the political and socio-cultural front. Bosnia's police remain embedded within a deeply-polarized political environment, and efforts both to depoliticize the police and to insulate them from political interference have produced generally disappointing results. Similarly, hopes and expectations have not been met in any meaningful way that serving Bosnian police officers and their political overseers could be socialized over time into accepting and internalizing Western standards of democratic policing, and even potentially serving as a model of renewed and functional multi-ethnicity for the rest of the country. As Gemma Collantes Celador (2005, p. 369) has observed, Bosnia's police reform experience offers precious little empirical support for the theory that "strong group identities can be subsumed by an overriding, apolitical, professional police identity."

Specifically, Bosnia's experience with police reform serves as a cautionary tale of using rule of law reforms as a substitute for political consensusbuilding as a means of advancing a peacebuilding agenda. In other words, it raises questions about the extent to which reforms aimed at advancing the rule of law - in the field of law enforcement as elsewhere - can be a cause, rather than a consequence, of broader socio-political change, particularly in contexts where domestic political actors possess robust powers of veto. An early example of this tension in practice relates to the role of police reform in the return of refugees and displaced persons to their pre-war homes in the 
war's aftermath. ${ }^{3}$ As noted above, the peace agreement was deeply ambiguous on the question of return, affirming the right of return while simultaneously acknowledging the legitimacy of ethnically-cleansed and ethnically-defined entities such as Republika Srpska. Thus, the return process was bitterly contested during the first half-decade of Dayton, and so police reformand specifically the re-generation of multiethnic police forces-emerged as one instrument through which the international community attempted to influence the process in favour of those wishing to return to their pre-war homes, especially in cases where returnees would be living as minorities. In order to both facilitate and promote such "minority returns," the IPTF championed the recruitment of minority police officers, with the explicit aim of helping to roll back ethnic cleansing "by offering returnees and wouldbe returnees some assurance that 'their' people are represented among the guardians of law and order in their former towns and villages" (ICG, 2002, p. 41). While ambitious targets were set for minority recruitment-fully 28 per cent of police in the Federation were to be drawn from minority communities - and considerable pressure applied to local officials both to accept and to implement such targets, minority police recruitment ultimately proved to be a marginal factor in the returnee process. Administrative footdragging on the part of local officials led to missed targets and delays in implementation, while cases of overt intimidation of minority police officers and the tendency for them to be assigned to desk positions raised suspicions about the extent to which minority police recruitment actually contributed to better security for minority returnees in general. Similarly, while potential minority returnees were clearly sensitive to security concerns, broader socio-economic considerations such as access to employment and public services were equally important factors in the calculus of return. Overall, in the absence of support on the part of domestic political elites for minority returns, the effort to promote them through the broader police reform process made relatively little impact.

A more dramatic example of the limits of police reform as an instrument of broader political change was the controversial Bosnia-wide police restructuring process that began in 2004. Part of the broader shift "from Dayton to Brussels," police restructuring was pitched not only as a means to help Bosnia prepare for EU accession, but also as a means of rationalizing a national policing system characterized by too many uncoordinated levels of policing at cantonal, entity, and state levels, and too few cooperation mechanisms (Perdan, 2008, p. 259). As the process unfolded, the police restructuring agenda was distilled down to three key principles; the shift of all legislative and budgetary competencies for policing to the state level, the removal of all political interference from operational policing, and the establishment of functional policing areas based on technical rather than political criteria. Acceptance of these three principles was made then a key condition for Bosnia to sign a Stabilization and Association Agreement (SAA) with the European Union.

Despite the considerable pressure brought to bear by the international 
community, the police restructuring process met with considerable domestic resistance, particularly from the Bosnian Serbs. While restructuring was framed by the international community in the context of bureaucratic rationalization and of bringing Bosnian policing into line with international and specifically European standards, for their part the Bosnian parties saw police reform "in terms of a domestic balance of power and not in terms of efficiency or the effectiveness of the police forces" (Juncos, 2011, p. 384). Bosnian opponents also saw through the "European standards" argument, rightly pointing out that the EU contains diverse models of policing, including models where policing jurisdictions quite clearly correspond to political jurisdictions (Collantes Celador, 2009, p. 239). The Bosnian Serbs in particular viewed the overall police restructuring process, not without justification, as a direct assault on the integrity and quasi-sovereignty of their entity. In a very real sense, the Bosnian Serb leadership was being asked to choose between the European Union and Republika Srpska, and these leaders made it clear that if they couldn't have both, they preferred the latter. In the end, the effort to instigate a radical restructuring of political authority in Bosnia through the mechanism of police reform-a restructuring which, in its centralizing tendencies, would have clearly favoured Bosnia's Muslim majority - unraveled completely. After a face-saving but relatively meaningless agreement which allowed Bosnia to sign an SAA, the Bosnian Serbs withdrew from the agreement in 2007. Shortly after this agreement was struck, a wider governance crisis began to take hold in Bosnia as relations declined between the country's entities and ethnicities, and police reform as well as the original three principles of police restructuring were relegated to the back burner of the country's reform agenda.

\section{Anti-Corruption}

The struggle against corruption in Bosnia represents a second key rule of law issue marked by an ongoing failure to consolidate progress and deepen reforms, to the extent that the country's current political crisis is now eroding earlier anti-corruption achievements. While the corruption question was at best a second-tier peacebuilding priority during the initial period of Dayton implementation, a 1999 New York Times article claiming that up to \$1 billion (US) in international reconstruction funds had disappeared into the pockets of corrupt Bosnian politicians raised key questions about the extent, and the costs, of corruption (Hedges, 1999). More generally, it was also becoming increasingly clear at the time that wartime alliances between organized criminals and nationalist political elites had survived the end of armed violence, and were integral elements of entrenched political power structures that stood in the way of peace implementation. Writing in 2000, Peter Singer described the increasing criminalization of the Bosnian body politic and the "tightening vise of corruption and cronyism" (2000, pp. 31-32), echoing earlier comments from the head of the Bosnia Mission of the Organization 
for Security and Co-operation in Europe (OSCE) that the nexus of "extremist politicians, the remnants of the old security services, and organized crime in this country represents the single greatest obstacle to democratic reform, economic investment, and membership in Euro-Atlantic institutions" (cited in Dziedzic, Rosen, \& Williams, 2002, p. 9).

With the growing acknowledgement of the pervasive threat posed by corruption to the broader peace process in Bosnia, the fight against corruption emerged as a central pillar of the internationally-driven strategy of peacebuilding through state building that was gathering steam at the turn of the millennium. In addition to the elaboration of an explicit anti-corruption agenda by the OHR, anti-corruption goals featured strongly in many of the institutional reforms undertaken during this period and were grounded in a four-pronged strategy of eliminating opportunities for corruption, working towards greater transparency in public institutions, strengthening controls and penalties, and fostering greater public awareness of the costs of corruption (OECD, 2005, p. 25). The creation of the State Border Service and reforms to the customs administration were motivated largely by the goal of reducing both fraud and the smuggling of people and goods at Bosnia's border crossings. Similarly, wide-ranging reforms to Bosnia's banking sector and tax bureaucracy were all aimed at least in part at reducing opportunities for graft and corruption within the public service. Meanwhile, a principle aim of justice sector reforms - including ongoing efforts to professionalize both the police and the judiciary - was not only to root out the corrupt and the criminalized within both institutions but also to strengthen the country's own capacity to detect and prosecute corruption. Concurrently, aggressive international moves against the economic bases of nationalist power structures - including the 2001 takeover, with the support of NATO forces, of the Mostar-based Hercegovacka Banka, which was alleged to be bankrolling a network of illegal parallel institutions in Croat-controlled Herzegovina - were accompanied by a growing willingness on the part of the High Representative to remove elected officials from office for corruption and abuse of office (Chandler, 2006).

Unquestionably, while such efforts made a difference in reining in the most egregious forms of corruption in post-Dayton Bosnia, it is equally clear that, in important ways, corruption "remains endemic as a way of life in Bosnia" (cited in Soberg, 2008, p. 718). Recently, a study ranked Bosnia last among European states in terms of its anti-corruption efforts, while a recent European Commission report sharply criticized the "very limited progress" made by Bosnia on this front (Jukic, 2011; Woehrel, 2012, p. 8). Along with unemployment, corruption continues to top public opinion polls among Bosnians of all ethnicities in terms of the country's most serious problems (Mantcheva, Karaboev, \& Warner, 2011, p. 16). Despite the growing sense that the corruption problem has worsened in recent years, there is little evidence that Bosnia's justice system is either willing or able to confront it: while neighboring Croatia delivered 142 verdicts on corruption-related cases in 2011, the corresponding figure in Bosnia was 11 (Jukic, 2011). 
From the perspective of Bosnia's struggling peace process, while it may be argued that administrative corruption is simply an unavoidable consequence of Bosnia's ongoing transition from a managed to a market economy, more troubling is the persistence of large-scale political corruption, and the perverse incentives it creates for those in power to resist any reforms that threaten their privileges. If a key objective of rule of law reform is to ensure that those in power operate within clear, objective, and enforceable rules, and are held accountable when they break these rules, then it is clear that much remains to be done to consolidate this aspect of the rule of law in post-war Bosnia. While the monopoly on power of the three wartime nationalist political parties - the Serb SDS, the Croat HDZ, and the Bosniak SDA-has been broken, it remains fair to say that nationalist power structures across Bosnia remain essentially intact. Even though a pluralism of sorts has emerged across Bosnia over the past decade, the basic pattern of political life remains largely unchanged: the country's politics remains rigidly segregated along ethnic lines, nationalist rhetoric continues to be the key currency of Bosnian political life, and the practice of reaping the spoils of office for the benefit of self or party continues to be the norm regardless of which configuration of political parties holds political power, be it at state, entity, or cantonal level. Unsurprisingly, therefore, Bosnian political parties are considered by Bosnians to be the most corrupt institutions in the country. Indeed, corruption is a major reason for the widespread disillusionment, or even disgust, with which ordinary Bosnians now respond to politics in general and to the political class in particular (Woehrel, 2012, p. 5). There is a strong sense, and evidence as well, that top business leaders and senior government officials are beyond the reach of the rule of law (ICG, 2011, p. 9). If anything, impunity of the elite has been reinforced over the past few years with the declining influence of the international community and the reassertion of zero-sum nationalist discourse, which has led to increased political pressure on both the police and the judiciary (Azinovic et al., 2011, pp. 5-6). At times, the country's complex consociational structures have also conspired against the anti-corruption struggle. While a recent report of the State Investigation and Protection Agency implicated Republika Srpska Prime Minister Milorad Dodik and a dozen other senior RS officials for corruption, misuse of office and fraud, the fact that the investigation of such allegations fell under the jurisdiction of the RS prosecutor meant that they were not seriously pursued (ICG, 2011, p. 9).

Ultimately, Bosnia's current crisis may be as much about class as about ethnicity, as a small political and economic elite continue to enjoy the benefits of an unreformed status quo while life for the vast majority of ordinary Bosnians is marked by continuing stagnation and growing hopelessness. For all the talk of Bosnia's transition to a free-market economy, it remains the case that for the ruling parties, the control of state-owned companies, as well as the control of access to private-sector opportunities from privatization deals to public procurement contracts, continue to be key sources of power, influence, and authority. To a large extent, the previous nexus between political 
parties and organized criminals has morphed into the nexus between political parties and legitimate public and private enterprise. As Christopher Chivvis and Harun Dogo (2010) have noted, "political leaders control, directly or indirectly, many of the main employment opportunities in the country where private sector employment is underdeveloped and public sector jobs are widely viewed as superior" (p. 110). In the case of state-owned companies in particular, not only do they provide outlets for party patronage, they also provide ruling parties with important sources of revenue; in the words of Srdjan Blagovcanin, the head of the Bosnian branch of Transparency International, "the essential problem is political corruption at the highest levels of government where political parties basically use public companies as cash machines" (cited in Jukic, 2011).

The fight against corruption in Bosnia over the past decade is a good example of "partial reform syndrome" (Richmond \& Franks, 2007, p. 31), in which institutional and legal reforms are put into place but fail to transform underlying socio-economic or political dynamics. Indeed, as part of its stated objective of joining the European Union, Bosnia has ratified a wide range of international instruments promoting public integrity and transparency, and as recently as 2010 has established a state-level Agency for Corruption Prevention and the Coordination of the Fight Against Corruption (Mantcheva et al., 2011). The fact that this agency remains an empty shell is further evidence of the limited ability of laws, or institutions, to promote change themselves. The Bosnian example also underlines the reality that, in the fight against corruption as elsewhere, "international peacebuilding actors are ... highly dependent on the cooperation of local actors, especially elites" (Cheng \& Zaum, 2012, p. 14). Indeed, observers often lament the lack of domestic political will to take up the fight against corruption, yet rarely investigate the sources of this absence. In Bosnia's case, it remains the case that, as Peter Singer noted more than a decade ago, "the forces of division are making too much money to let go of the status quo" (2000, p. 36). Political corruption in Bosnia also continues to be justified in the context of the country's unresolved conflict; to the extent that parties portray themselves as essential defenders of their national interest, corruption is often rationalized in the name of this interest. Conversely, heightened ethno-nationalist rhetoric also provides a convenient cover for, or distraction from, business as usual in public life. RS President Milorad Dodik's popularity within the RS remains high, despite the odour of corruption that surrounds him and his close associates, largely because of his very public feud with both senior Bosniak figures and with the broader international community on the question of the future status of Republika Srpska within Bosnia.

\section{Conclusion}

In the aftermath of constitutional changes imposed by the High Representative as part of the international community's broader state building agenda 
in Bosnia, Robert Hayden noted in 2005 that the underwhelming impact of such changes could be read as "a cautionary tale about the limits of constitutionalism when there is no social consensus on the character or even the existence of the nation and, thus, not on the establishment of the state" (2005, p. 230). Seven years later, a similar conclusion could be drawn about the limits of rule of law reform under similar conditions. For local parties in such a context, respect for, and adherence to, abstract and externally-imposed principles such as justice, accountability, and transparency not only entails greater costs than benefits, but also pales in significance when set alongside zero-sum political contests over fundamentally existential issues and the more prosaic pursuit of political and economic self-interest. Reforms may be accepted in response to external carrots and/or sticks, but are rarely embraced with any enthusiasm or implemented with any determination by those whose power they promise to constrain. As the Bosnian case shows, the more rule of law reforms threaten to subvert existing structures of power-in which the root causes of the original conflict often reside - the more likely they are to be resisted by those currently in positions of power.

Such a conclusion, which can be drawn with equal validity from other peacebuilding contexts, including those as varied as Haiti, Sierra Leone, and Afghanistan, presents a serious dilemma for contemporary peace builders. If domestic political elites are both indispensable partners and primary impediments in rule of law implementation, precisely how should international actors proceed in their engagement with such actors? Even allowing for sufficient political will on the part of international actors to confront recalcitrant domestic elites head-on, it is not clear that more forceful approaches will produce better results. Indeed, one of the lessons of Bosniaonce described as "the world capital of interventionism" (cited in Chandler, 2001, p. 116) - relates to the inherent limits of international power and authority in post-conflict spaces. If intrusive social engineering on the part of international actors has failed to transform Bosnia, it is hard to imagine how it could succeed elsewhere. Conversely, despite many recent calls for the international community to approach the challenges of peacebuilding with greater humility, it is not entirely clear what this implies in a practical sense. To the extent that it implies leaving problematic domestic power structures untouched and unchallenged, greater humility may translate into little more than an abandonment of rule of law and human rights as policy goals, and an admission that outsiders can do little to tackle the fundamental obstacles to peace in post-conflict environments. Given these options, therefore, it is unsurprising that international rule of law promoters often unproductively oscillate between coercion and co-option in their efforts to encourage domestic elites to take genuine ownership over rule of law reforms, which contributes to the suboptimal equilibrium of what Michael Barnett and Christoph Zurcher (2009) have termed "compromised peacebuilding."

At the very least, the challenge of successfully charting a course between accepting the political status quo and fundamentally transforming it requires more nuanced approaches that advance the rule of law even while accepting 
its limits as an instrument of deep political transformation. In Bosnia's case, the recent debacle around police reform provides a clear example of the dangers of promoting an explicitly political agenda under the guise of technocratic and legalistic reforms to a key rule of law institution. The political agenda in this case is a restructuring of relations between the state and the entities. In contrast, the more successful example of property law implementation, through which displaced Bosnians regained legal rights to property owned or occupied by them prior to their displacement, suggests in certain circumstances that it is possible to detach rule of law issues from their more contentious and divisive political connotations. While early efforts to implement property rights were explicitly associated with the broader return agenda — and were thus resisted and/or exploited by ethnic nationalists across Bosnia-property law implementation gradually came to focus more on the rights of individuals to re-claim their property, which they could subsequently re-occupy or sell as they saw fit, and less on the hotly-contested issue of whether property restitution could be, or should be, an instrument for reversing ethnic cleansing (Williams, 2006, p. 39). In this case at least, the pursuit of more modest goals lowered the political temperature around the issue, allowed political obstructionism to be overcome, and ultimately facilitated a process through which local authorities restored hundreds of thousands of properties to their rightful owners (Philpott, 2005, p. 21). Whatever else one might make of the comparison between these two episodes, the success of the one and failure of the other points to the perils of using rule of law reforms as instruments for the achievements of broader political goals. Rule of law promotion, in this sense, may be a poor substitute for an ongoing process of conflict resolution aimed at crafting durable solutions acceptable to all relevant parties.

At an even deeper level, the dilemmas posed by post-conflict rule of law promotion raise profound questions about the processes through which the values associated with the rule of law come to be grounded within particular societies, post-conflict or otherwise. As discussed above, the growing attention being paid to questions of culture, and more specifically to the possibilities for grafting Western rule of law traditions onto domestic traditions of order and justice, represents one means through which peace-builders have sought to ground rule of law norms in locally-legitimate practices and structures. Yet, while the acceptance of both the inevitability and desirability of hybridity represents an important corrective to the early triumphalism of the liberal peacebuilding project, it may provide only a partial answer to the broader questions raised here about the relationship among power, peacebuilding and the rule of law, in large part because these traditional practices may contribute to, and justify, the concentration of power in the hands of an unaccountable few (Mac Ginty, 2008).

Finally, it is almost certainly the case that the rule of law in its more substantive forms, in which all citizens are equal before the law and those in power can also be held accountable under the law for their actions, can emerge only through the complex, long-term dynamics of domestic politics. 
Indeed, in Western contexts, the rule of law emerged as part of a complex and dynamic process of negotiation and re-negotiation between governors and the governed that can be traced, in the English case at least, as far back as the Magna Carta. Not only does this suggest that the development of the rule of law requires much longer time frames than those associated with contemporary peacebuilding operations, it also suggests that, in the case of Bosnia, the failures of the rule of law may be closely associated with the failures of democracy. Between the consociational nature of the Bosnian settlement, which ensured that all political questions and contests would be filtered through the lens of ethnicity, and the international community's intrusive statebuilding agenda, which made Bosnia's elected authorities more accountable to the international community than to their own citizens, the dynamics of peacebuilding in Bosnia have conspired against the emergence of "normal democratic politics" in which public opinion matters and in which citizens can occasionally pass judgment on the performance of their elected officials. In Bosnia's case, however, elections have served too often as little more than ethnic censuses, while for a considerable period, real decision-making power resided almost exclusively in the Office of the High Representative. In combination, these dynamics have created an accountability-free political class and an impoverished democratic process that generates no pressure on political elites to either advance or abide by the rule of law.

Reversing such trends and overcoming the peacebuilding and state building stalemate that currently persists in Bosnia will require considerable changes to both top-down and bottom-up political dynamics. No one should expect this reversal to come quickly, or easily. After 2006, the shift to a less-intrusive statebuilding strategy on the part of the international community, accompanied by a growing disinclination to deploy the Bonn powers, has placed responsibility for Bosnia's future back in the hands of its elected representatives and thereby has created at least the potential for domestically-driven reform and greater democratic accountability. Indeed, the post-Bonn era was marked by some initial optimism on the constitutional reform front. Reform of Bosnia's dysfunctional Dayton-era constitution is widely considered as a prerequisite to the emergence of a more constructive, less-polarized, form of democratic politics. However, the inability to overcome deep divisions over the very nature of the Bosnian state doomed constitutional reform talks and eventually deepened the ethnic divide among the country's political elites. As I have noted elsewhere, the paradox is that while reconsidering the constitutional arrangements negotiated at Dayton inevitably will open old wounds and revive old hostilities, it is very difficult to imagine how Bosnia can escape chronic, debilitating political crisis without developing new, consensual political arrangements that are broadly acceptable to all of the country's key political actors (Donais, 2012, p. 93).

Similarly, the renewal of democratic politics in Bosnia, which is a politics centred less on zero-sum ethnic competition and more on constructive statesociety relations underpinned by the progressive consolidation of the rule 
of law, will also require a re-engaged civil society and electorate. Ironically, the growing recognition of the importance of bottom-up or participatory peacebuilding (Chopra \& Hohe, 2004) has coincided with the widespread abandonment of such practices by international actors in Bosnia. Today, Bosnian civil society is weak and fragmented, and many voters have given up on the possibilities for achieving progressive change through democratic processes. While it is unclear whether there is any appetite among the international presence in Bosnia to re-engage with questions of civil society peacebuilding as one means of bridging the state-society divide and of beginning the inevitably long-term process of re-negotiating a social contract, numerous entry points exist through which such a re-engagement could be initiated. There is no reason, for example, why constitutional reform discussions must remain the exclusive domain of political elites, and engaging Bosnians in a constructive discussion about their own future might begin usefully with facilitated, community-level dialogues on basic constitutional questions. Similarly, as Stefanie Kappler and Oliver Richmond (2011) have recently argued, the push to replicate Western forms of civil society in Bosnia and elsewhere have often led to the neglect of "deep" civil society (p. 274). Given the widely-recognized failures of conventional civil society building efforts, it may be time to reconsider the peacebuilding potential of associational forms such as religious communities that continue to act as repositories of social capital even if they have previously been considered insufficiently liberal to merit outside support. Finally, while statelevel democratic processes remain both paralyzed and beyond the reach of ordinary citizens, considerable opportunity continues to exist for efforts aimed at strengthening local-level democracy. As Paul Risley and Timothy Sisk (2005) have noted, legitimate local-level governance can not only enable the delivery of essential services, it can also enable ordinary citizens to exercise both voice and agency over decisions that affect their lives directly, facilitating both community engagement and cohesion and contributing over the longer term to the development of a participatory democratic culture.

One of the key lessons to be drawn from Bosnia's post-Dayton experience with the rule of law ultimately relates to the limits of externally-driven social engineering, especially in the absence of broad-based social and political consensus among those who have to live with such reforms on both the means and the ends of the reform process. As the broader discourse around state building increasingly turns to the importance of strengthening state-society relations (OECD, 2011), it will be imperative to focus less on the agency of international actors as architects, implementers and enforcers of the rule of law in post-conflict environments, and more the ways in which outsiders can facilitate domestic political dynamics that support, over the longer term, the emergence of the rule of law. 


\author{
Notes \\ 1 Author interview with Kurt Bassuener, Democratization Policy Council, Sarajevo, \\ October 2011. \\ 2 Author interview, Sarajevo, May 2009. \\ 3 Parts of this section are drawn from Donais (2006).
}

\title{
References
}

Azinovic, V., Bassuener, K. \& Weber, B. (2011). Assessing the potential for renewed ethnic violence in Bosnia and Herzegovina: A security risk analysis. Sarajevo: Atlantic Initiative and Democratization Policy Council. Retrieved from http://www.atlanticinitiative.org/ images/stories/ai/pdf/ai-dpc\%20bih\%20security\%20study\%20final\%2010-9-11.pdf

Barnett, M., \& Zurcher, C. (2009). The peacebuilder's contract: How external statebuilding reinforces weak statehood. In R. Paris \& T. Sisk (Eds.), The dilemmas of statebuilding: Confronting the contradictions of postwar peace operations (pp. 23-52). New York/ Abingdon: Routledge.

Belloni, R. (2009). Bosnia: Dayton is dead! Long live Dayton! Nationalism and Ethnic Politics, 15(3), 355-375.

Betts, A. (2005). Should approaches to post-conflict justice and reconciliation be determined globally, nationally or locally? European Journal of Development Research, 17(4), 735-752.

Call, C., \& Wyeth, V. (Eds.) (2008) Building states to build peace. Boulder/London: Lynne Rienner.

Chandler, D. (2001). Bosnia: The democracy paradox. Current History, 100(644), 114-119.

Chandler, D. (2004). The problems of "nation-building": imposing bureaucratic "rule from above." Cambridge Review of International Affairs, 17(3), 577-591.

Chandler, D. (2006). Building trust in public institutions? Good governance and anti-corruption in Bosnia and Herzegovina. Ethnopolitics, 5(1), 85-99.

Cheng, C. \& Zaum, D. (2012). Selling the peace? Corruption and post-conflict peacebuilding. In C. Cheng and D. Zaum (Eds.), Corruption and post-conflict peacebuilding: Selling the peace? (pp. 1-25). Abingdon/New York: Routledge.

Chopra, J. \& Hohe, T. (2004). Participatory peacebuilding. In T. Keating and W.A. Knight (Eds.), Building sustainable peace (pp. 241-261). Edmonton and Tokyo: University of Alberta Press/ UN University Press.

Chivvis, C. \& Harun D. (2010). Getting back on track in Bosnia-Herzegovina. The Washington Quarterly, 33(4), 103-118.

Collantes Celador, G. (2005). Police reform: Peacebuilding through "democratic policing"? International Peacekeeping, 12(3), 364-376.

Collantes Celador, G. (2009). Becoming "European" through police reform: A successful strategy in Bosnia and Herzegovina? Crime, Law and Social Change, 51, 231-242.

Davidson, D. (2009). Recapitulating Yugoslavia: Culture, politics, and state-building in Bosnia and Herzegovina. German Marshall Fund of the United States Policy Brief. Retrieved from http://www.gmfus.org/wp-content/blogs.dir/1/files_mf//galleries/ct_publication_attach ments/Davidson_Yugoslavia_Final.pdf

Dempsey, J. \& Coburn, N. (2010). Traditional dispute resolution and stability in Afghanistan. United States Institute of Peace Peacebrief 10. Retrieved from http:/www.usip.org/files/ resources/PB\%2010\%20Traditional\%20Dispute\%20Resolution $\% 20$ and $\% 20$ Stability $\% 20$ in\%20Afghanistan.pdf

Donais, T. (2006). The limits of post-conflict police reform. In M. Innes (Ed.), Bosnian security After Dayton: New perspectives (pp. 173-190). Abingdon/New York: Routledge.

Donais, T. (2012). Peacebuilding and local ownership: Post-conflict consensus-building. Abingdon/New York: Routledge.

Dziedzic, M., Rosen, R., \& Williams, P. (2002). Lawless rule versus rule of law in the Balkans. United States Institute of Peace Special Report No. 97. Retrieved from http://www.usip.org/ 
publications/lawless-rule-versus-rule-law-balkans

Fatton, R. (2002). Haiti's predatory republic: The unending transition to democracy. Boulder: Lynne Rienner.

Hayden, R. (2005). "Democracy" without a demos? The Bosnian constitutional experiment and the intentional construction of nonfunctioning states. East European Politics and Societies, 19(2), 226-259.

Hedges, C. (1999, August 17). Leaders in Bosnia are said to steal up to \$1 billion. New York Times.

International Crisis Group (ICG). (2002). Policing the police in Bosnia: A further reform agenda. ICG Europe Report No. 130, Sarajevo. Retrieved from http://www.crisisgroup.org/ en/regions/europe/balkans/bosnia-herzegovina/130-policing-the-police-in-bosnia-a-furtherreform- agenda.aspx

International Crisis Group (ICG). (2011). Bosnia: What does Republika Srpska want? ICG Europe Report No. 214, Sarajevo. Retrieved from http://www.crisisgroup.org/ /media/ Files/europe/balkans/bosnia-herzegovina/214\%20Bosnia\%20---\%20What\%20Does\%20 Republika\%20SRPSKA\%20Want.pdf

International Crisis Group (ICG). (2012). Bosnia's Gordian Knot: Constitutional reform. ICG Europe Briefing No. 68, Sarajevo. Retrieved from http://www.crisisgroup.org/ /media/Files/ europe/balkans/bosnia-herzegovina/b068-bosnias-gordian-knot-constitutional-reform.pdf

Jensen, E.G. (2008). Justice and the rule of law. In C. Call and V. Wyeth (Eds.), Building States to Build Peace (pp. 119-142). Boulder/London: Lynne Rienner.

Jukic, E. (2011, December 14). Transparency slates Bosnian corruption. Balkan Insight. Retrieved from http://www.balkaninsight.com/en/article/transparency-slates-bosnian-corruption

Juncos, A. (2011). Europeanization by decree? The case of police reform in Bosnia. Journal of Common Market Studies, 49(2), 367-389.

Kappler, S. \& Richmond, O. (2011). Peacebuilding and culture in Bosnia and Herzegovina: Resistance or emancipation? Security Dialogue, 42(3), 261-278.

Kingston, P. (2012). The pitfalls of peacebuilding from below: Governance promotion and local political processes in postconflict Lebanon. International Journal, 67(2) 333-350.

Mac Ginty, R. (2008). Indigenous peace-making versus the liberal peace. Cooperation and Conflict, 43(2), 139-163.

Mac Ginty, R. (2011). International peacebuilding and local resistance: Hybrid forms of peace. New York: Palgrave Macmillan.

Mantcheva, D., Karaboev, S., \& Warner, J. (2011). Countering corruption in Bosnia and Herzegovina: 2001-2011. Sofia/Sarajevo: Center for the Study of Democracy and Center for Investigative Reporting. Retrieved from http://www.csd.bg/artShow.php?id=16084

Muehlmann, T. (2007). International policing in Bosnia and Herzegovina. The issue of behavioural reforms lagging behind structural reforms, including the issue of reengaging the political elite in a new system. European Security, 16(3-4), 375-396.

National Democratic Institute (NDI). (2010). Public opinion poll: Bosnia and HerzegovinaAugust 2010. Retrieved from http://www.ndi.org/files/NDI_Bosnia_Poll_Report_August_2010.pdf

Organization for Economic Co-operation and Development (OECD). (2005). International cooperation to fight corruption in southeastern Europe: achievements, lessons learned and future challenges. Scoping Paper, Anti-Corruption Network for Transition Economies. Retrieved from http://www.oecd.org/corruption/acn/library/37152800.pdf

Organization for Economic Co-operation and Development (OECD).(2011). Supporting statebuilding in situations of conflict and fragility. Paris: OECD. Retrieved from http://browse.oecdbookshop.org/oecd/pdfs/free/4311031e.pdf.

Park, A. S. J. (2010). Peacebuilding, the rule of law and the problem of culture: Assimilation, multiculturalism, deployment. Journal of Intervention and Statebuilding, 4(4), 413-432.

Paris, R. (2004). At war's end: Building peace after civil conflict. Cambridge: Cambridge University Press.

Perdan, S. (2008). Bosnia: SSR under international tutelage. In T. Donais (Ed.), Local ownership and security sector reform (pp. 253-272). Zurich/Berlin: Lit Verlag.

Peterson, J. (2010). "Rule of law" initiatives and the liberal peace: The impact of politicized reform in post-conflict states. Disasters, 34(S1), S15-S39.

Philpott, C. (2005). Though the dog is dead, the pig must be killed: Finishing with property 


\section{Timothy Donais}

restitution to Bosnia-Herzegovina's IDP's and Refugees. Journal of Refugee Studies, 18(1), $1-24$.

Pouligny, B. (2005). Civil society and post-conflict peacebuilding: Ambiguities of international programmes aimed at building "new" societies. Security Dialogue, 36(4), 495-510.

Richmond, O. \& Franks, J. (2007). Liberal hubris? Virtual peace in Cambodia. Security Dialogue, 38(1), 27-48.

Risley, P. \& Sisk, T. (2005). Democracy and United Nations Peace-Building at the Local Level: Lessons Learned. Stockholm: International Institute for Democracy and Electoral Assistance. Retrieved from http://www.idea.int/publications/democracy_un/index.cfm

Singer, P. (2000). Bosnia 2000: Phoenix or flames? World Policy Journal, 17(1), 31-37.

Soberg, M. (2008). The quest for institutional reform in Bosnia and Herzegovina. East European Politics and Societies, 22(4), 714-737.

Sorensen, G. (2006). Liberalism of restraint and liberalism of imposition: Liberal values and world order in the new millennium. International Relations, 20(3), 251-272.

Stromseth, J., Wippman, D., \& Brooks, R. (2006). Can might make rights? Building the rule of law after military interventions. Cambridge: Cambridge University Press.

Tamanaha, B. (2004). On the rule of law: History, politics, theory. Cambridge/New York: Cambridge University Press.

Williams, R. (2006). The significance of property restitution to sustainable return in Bosnia and Herzegovina. International Migration, 44(3), 39-61.

Woehrel, S. (2012, February 29). Bosnia: Current issues and US policy. Congressional Research Service Report for Congress. Retrieved from http://www.fas.org/sgp/crs/row/R40479.pdf 